\title{
Impacts and Potential Mitigation of Road Mortality for Hedgehogs in Europe
}

\author{
Lauren J. Moore ${ }^{1, *} \mathbb{\infty}$, Silviu O. Petrovan ${ }^{2}$, Philip J. Baker ${ }^{3}$, Adam J. Bates ${ }^{1} \mathbb{D}$, Helen L. Hicks ${ }^{1} \mathbb{D}$, \\ Sarah E. Perkins ${ }^{4}(\mathbb{D})$ and Richard W. Yarnell ${ }^{1}$ (I) \\ 1 School of Animal, Rural and Environmental Sciences, Nottingham Trent University, Southwell NG25 0QF, \\ Nottinghamshire, UK; adam.bates@ntu.ac.uk (A.J.B.); helen.hicks@ntu.ac.uk (H.L.H.); \\ richard.yarnell@ntu.ac.uk (R.W.Y.) \\ 2 Department of Zoology, University of Cambridge, The David Attenborough Building, Cambridge CB2 3QZ, \\ Cambridgeshire, UK; sop21@cam.ac.uk \\ 3 School of Biological Sciences, University of Reading, Reading RG6 6AH, Berkshire, UK; \\ p.j.baker@reading.ac.uk \\ 4 School of Biosciences, Cardiff University, Sir Martin Evans Building, Cardiff CF10 3AX, UK; \\ perkinss@cardiff.ac.uk \\ * Correspondence: lauren.moore@ntu.ac.uk
}

Received: 29 June 2020; Accepted: 26 August 2020; Published: 28 August 2020

check for updates

Simple Summary: The environmental impacts of transport infrastructure are attracting substantial research focus and road-induced mortality of wildlife is perhaps the most conspicuous impact of roads. Hedgehogs are a common victim of traffic collisions in Europe and several hedgehog species are showing marked population declines across their range. This review aims to consolidate current knowledge on the impacts of road mortality on the viability of populations of the five hedgehog species in Europe and identify research gaps. Previous studies have shown that roads are a major source of mortality for hedgehogs and that individuals with greater net movement, generally males, have the greatest likelihood of mortality. Road mortality also contributes to population isolation. More research is needed into how different individuals perceive, use and cross roads, as well as the efficacy of different mitigation measures (e.g., wildlife crossing structures) designed to reduce road mortality and population isolation. Assessing whether local hedgehog populations are at risk of extirpation or further declines due to road mortality is a prerequisite for effective conservation in environments affected by continuously developing road networks.

Abstract: Transport infrastructure is a pervasive element in modern landscapes and continues to expand to meet the demands of a growing human population and its associated resource consumption. Road-induced mortality is often thought to be a major contributor to the marked declines of European hedgehog populations. This review synthesizes available evidence on the population-level impacts of road mortality and the threat to population viability for the five hedgehog species in Europe. Local and national studies suggest that road mortality can cause significant depletions in population sizes, predominantly removing adult males. Traffic collisions are a probable cause of fragmentation effects, subsequently undermining ecological processes such as dispersal, as well as the genetic variance and fitness of isolated populations. Further studies are necessary to improve population estimates and explicitly examine the consequences of sex- and age-specific mortality rates. Hedgehogs have been reported to use crossing structures, such as road tunnels, yet evaluations of mitigation measures for population survival probability are largely absent. This highlights the need for robust studies that consider population dynamics and genetics in response to mitigation. In light of ongoing declines of hedgehog populations, it is paramount that applied research is prioritised and integrated into a holistic spatial planning process. 
Keywords: road mortality; collision; fragmentation; movement; demography; population viability; mitigation; road ecology; hedgehogs

\section{Introduction}

The last century has been characterised by intense modification of the natural landscape, and road networks are now pervasive in most landscapes on Earth [1,2]. Interest in the ecological impacts of roads has grown since the mid-20th century, with formal recognition of a new field, road ecology, by Forman and Alexander in 1998 [3]. This branch of ecological research has revealed the extensive role that roads play in direct and indirect habitat loss and alteration. Traffic noise, light pollution and chemical pollution (salt, heavy metals, herbicides) are all identified as important correlates of habitat modification, fragmentation and changes in animal movement in road-dominated environments [4].

Perhaps the most conspicuous impact of roads are wildlife-vehicle collisions (WVCs) that result in the death of billions of animals worldwide every year [5]. Biological characteristics of the animals themselves (e.g., age, sex and movement), biotic factors (e.g., time of day, season), traffic and road characteristics (e.g., traffic volume, road width, tortuosity) and environmental characteristics (e.g., topography, neighbouring habitat structure) all interact to form a species-specific spatiotemporal distribution of WVCs [6]. The consequences of road mortality are typically two-fold: (1) direct depletion of individuals from a population and/or (2) fragmentation of populations and reduced gene flow [7-9]. Importantly, these consequences can alter meta-population structure and population fitness, in turn increasing the risk of local extinction [10]. Roads are therefore considered responsible for the nationwide decline of certain species and a limiting factor in the recovery of others [11,12]. The growing literature on road ecology has been largely motivated by WVCs that are of legislative or conservation concern and/or which give rise to economic or human safety issues, such as collisions with deer [6]. In comparison, fewer studies have examined smaller mammal species, such as hedgehogs.

There are five species of hedgehog with all or part of their range in Europe, although hedgehog taxonomy has been debated due to contradictions between molecular and morphological phylogenies [13]. The West European hedgehog (Erinaceus europaeus) is distributed over Ireland, Britain and western mainland Europe. The Algerian hedgehog (Atelerix algirus) is present in North Africa and was introduced to Spain and several Mediterranean islands [14]. Moreover, the northern white-breasted hedgehog (Erinaceus roumanicus) is distributed throughout Central and Eastern Europe, whilst the southern white-breasted hedgehog (Erinaceus concolor) is present in Eastern Europe and Southwestern Asia [15]. The long-eared hedgehog (Helmiechinus auritus) maintains part of its predominately Middle Eastern range in Cyprus and Ukraine [13].

Although hedgehog density has been reported to be up to 35\% lower near roads [16], road-killed hedgehogs are a very familiar sight across Europe and are frequently the main mammal roadkill recorded in citizen science projects and expert multispecies roadkill surveys $[17,18]$. For example, an estimated 113,000-340,000 E. europaeus individuals are killed on roads every year in the UK [19] and The Netherlands [20], and 230,000-350,000 individuals every year in Belgium [21]. Comparisons between short-term studies are difficult as roadkill rates can fluctuate with changes in hedgehog density, road conditions and traffic volume [22]. Alternatively, long-term roadkill data are valuable to observe changes in temporal behaviour or monitor population trends [23]. For example, Recihholf [24] and Müller [25] found hedgehog road mortality to have steadily decreased since the 1970s in Germany, and Wilson and Wembridge [26] found similar patterns in the UK since 2001. It is claimed that these changes reflect the marked declines over the past two decades of E. europaeus in several countries across Europe [25,27]. A. algirus has also shown reduced abundance and local extinctions in its introduced range in Europe [14]. However, sufficient hedgehog population data to identify declines are currently limited to the UK [28,29], the Netherlands [30] and, to a lesser extent, Denmark [31] and Germany [25]. Traffic-related mortality has been implicated as a significant component of hedgehog 
population declines and also constitutes a welfare concern $[8,19,24,32]$. In recent times, the field has used nationwide monitoring schemes such as "Project Splatter", a citizen science study in the UK that collates such data [33]. Studies using nationwide data have demonstrated broad spatiotemporal patterns; hedgehog roadkill hotspots are associated with suburban areas and grassland, as well as the breeding season in late spring and early summer [22,32]. Records of hedgehog road mortality have also been used to estimate annual road mortality [19-21], track epizootics [22] and have the potential to estimate population abundance [34,35]. Substantial gaps in knowledge remain, however, about whether roads affect long-term population persistence. Likewise, the use of appropriate techniques to evaluate the complexity of the impact (e.g., population modelling using collected demographic data) have received little attention [36].

Investigating the population-level impacts of road mortality is of both theoretical and applied importance. It is likely that Europe is already the most fragmented continent due to transport infrastructure [2,37] and road networks continue to expand rapidly. In the UK alone, an average of $70,000 \mathrm{~km}$ of new roads are built every year [38] and many existing roads are modernised or widened throughout Europe [39]. Road development, however, is not consistent across European countries [37]. Coupled with the assertion that road mortality is the leading cause of human-induced vertebrate mortality on land [3], road ecology is a critical frontier of applied scientific research. As several European hedgehog species are declining and disproportionately represented in roadkill records [21], understanding how important road mortality is for population trends is a necessary step for hedgehog conservation. This review aims to consolidate the current knowledge on the consequences of road mortality for the viability of hedgehog populations in Europe. We used online databases to search for and appraise published, peer-reviewed articles on hedgehog road ecology, complemented by government reports on road statistics. This review synthesises information on the possible direct role that road mortality plays in population declines. It then discusses the individual-level risk of road mortality and the contribution of hedgehog-vehicle collisions to much-discussed fragmentation effects and associated genetic heterozygosity. Finally, this review identifies opportunities for road mitigation for hedgehogs, current knowledge gaps and priorities for future research.

\section{Does Road Mortality Really Reflect Population Persistence?}

It is difficult to confirm or refute the impact of road mortality on population trends because survival probabilities depend on a complex set of inter-related factors [40]. Several criteria exist to evaluate the ecological effects of road mortality. For example, the total number of road-killed animals must be considered in the context of population size [19], reproductive output, immigration and emigration rates [41] and whether WVCs are compensatory or additive to other forms of mortality [5]. To date, research has only partially met these criteria. Recent year-round studies have evidenced an average $0.001-3.65$ hedgehog casualties/ $\mathrm{km} /$ year for all European species across several European countries (Table 1). 
Table 1. Estimates of the mean number of hedgehogs killed on roads per kilometre per year in different European countries. Data are derived from systematic, year-round studies.

\begin{tabular}{|c|c|c|c|c|c|c|}
\hline Species & Country & $\begin{array}{l}\text { Year(s) of } \\
\text { Study }\end{array}$ & $\begin{array}{l}\text { Mean Number of Road } \\
\text { Casualties/km/Year }\end{array}$ & Surveyed Road Types & Habitats along Survey Route & Reference \\
\hline \multirow{4}{*}{ E. europaeus } & Ireland & 2008-2010 & 0.001 & National and regional roads & Residential, rural, woodland and built-up areas & [42] \\
\hline & Finland & 2004-2005 & 0.007 & National, regional and local roads & Residential, forests and built-up areas & [43] \\
\hline & Spain & 2001-2003 & $0.76-1.42$ & National roads & $\begin{array}{ll}\text { Forests } \\
\text { F }\end{array}$ & [44] \\
\hline & Slovakia & 2000-2002 & 1.6 & National, regional and local roads & Agricultural land, forests and nature preserves & [45] \\
\hline $\begin{array}{l}\text { E. europaeus and } \\
\text { E. concolor }\end{array}$ & Poland & $2001-2003$ & 0.07 & National, regional and local roads & Arable land and built-up areas & [46] \\
\hline A. algirus & Lanzarote & 2010-2011 & 0.65 & National, regional and local roads & Urban areas and Badlands & [18] \\
\hline \multirow{5}{*}{ E. roumanicus } & Bulgaria & 2017 & $0.06-0.08$ & National and regional roads & Rural areas & [47] \\
\hline & Bulgaria & 2015-2017 & 0.23 & National roads & Arable land, riparian vegetation and forests & [17] \\
\hline & Ukraine & 2000-2009 & 0.73 & National, regional and local roads & Urban areas and forests & [48] \\
\hline & Slovakia & 2008-2012 & $1.52-2.68$ & National roads & Agricultural land, grasslands, forest, riparian and built-up areas & [49] \\
\hline & Ukraine & 2002-2005 & 3.65 & National roads & Marshes, forests and urban areas & [50] \\
\hline
\end{tabular}


Counts of the hedgehogs killed on roads indicate the extent of (lethal) collisions with vehicles and can be used to quantify differences between species, countries and road types if the survey methodology is clearly described. However, they do not indicate the relative importance of traffic-related deaths in the context of populations as a whole [5], and there are issues of standardisation between studies due to differences in study design, effort, frequency and duration. Notably, these issues include accurately accounting for variable carcass persistence [51,52]. Examining the proportion of a population killed on roads every year is more informative. Previous studies of E. europaeus have calculated that traffic casualties amount to $9-26 \%$ of the total (nationwide) population size in The Netherlands [53] and $10-30 \%$ in the UK [19], assuming the population estimates are accurate [28]. At the local scale, previous studies have used capture-mark-recapture methods to identify an annual loss of 3-22\% of local E. europaeus populations on roads in Sweden [54] and 24\% in Poland [46]. Examining the proportional loss at the local scale is instrumental for targeted conservation action. This is because the impact of roads may be different between local populations due to regional variation in habitat type, quality, population densities and road networks [55].

Another promising indication of the population-level effects of road mortality is to compare it with mortality from other sources and identify its contribution to cumulative annual mortality. This can be used to assess the impact of traffic collisions on the mortality-recruitment ratio [5]. E. europaeus is the most studied hedgehog species worldwide and mortality of the species has been investigated using radio-tracking methods [43], capture-mark-recapture methods [54] and data from rescue centres [56] (Table 2). It should be noted that the small sample sizes in the reported studies in Table 2 and their study design can skew the relative importance of a cause of death, and that there will naturally be local variation in the occurrence of each mortality factor. Although the studies are an important first step in refining an understanding on mortality, the results should be interpreted with caution. The studies suggest that road traffic is consistently in the top three most common causes of death for hedgehogs, alongside illness and natural predation, supporting the narrative that traffic mortality potentially places substantial pressure on population dynamics. The magnitude of this effect will depend on the ability of populations to compensate for additional mortality by increased survival and/or reproduction, for example, with second litters [57]. Determining how plausible compensation is for hedgehogs is hampered by a lack of data on female hedgehog fecundity, such as the proportion of females that breed successfully, the mean number of litters per female annually and mean litter size, as well as juvenile survival rates. However, the evidence for ongoing hedgehog declines suggests that compensation might not be occurring [27]. It is likely that the declines of hedgehog populations across Europe are a result of a combination of factors. For example, intensified agricultural practices, molluscicide and rodenticide poisoning, badger predation and loss of habitat have also been raised as important correlates of reduced population density and local extinction risk [24,28,58-60]. Disentangling the relative impact of factors to population demography, which is likely to be area-specific, remains a principal goal to improve hedgehog conservation. 
Table 2. Percentage of deaths by different sources for studied E. europaeus individuals in Europe.

\begin{tabular}{|c|c|c|c|c|c|c|c|c|c|c|}
\hline Location & $\begin{array}{l}\text { Year of } \\
\text { Study }\end{array}$ & $\begin{array}{l}\text { Number of } \\
\text { Individuals }\end{array}$ & Roads & $\begin{array}{c}\text { Natural } \\
\text { Predation } \\
\text { (Badger and Fox) }\end{array}$ & $\begin{array}{c}\text { Unnatural } \\
\text { Predation } \\
\text { (Dog and Cat) }\end{array}$ & Illness $^{a}$ & Poison & Other ${ }^{b}$ & Unknown & Reference \\
\hline UK and The Netherlands & 1999 & $\sim 83580$ & 8.8 & Not included & 2.3 & 58.5 & 4.3 & 26.0 & Not included & [56] \\
\hline UK & 1988 & 109 & 78.0 & Not included & Not included & Not included & 2.8 & 1.8 & 17.4 & [61] \\
\hline UK & 1981 & 22 & 18.2 & 31.8 & 13.6 & Not included & 4.5 & 31.8 & Not included & [62] \\
\hline UK & 1992 & 8 & 25.0 & 75.0 & Not included & Not included & Not included & Not included & Not included & [63] \\
\hline UK & 2019 & 7 & 43.0 & 43.0 & Not included & 14.0 & Not included & Not included & Not included & [64] \\
\hline UK & 1998 & 7 & 57.0 & 14.0 & Not included & 14.0 & Not included & 14.0 & Not included & [65] \\
\hline Finland & 2016 & 106 & 72.6 & Not included & 0.9 & 20.7 & Not included & 1.8 & 4.0 & [43] \\
\hline Denmark & 2019 & 9 & Not included & Not included & 22.0 & 22.0 & $11.0^{\mathrm{c}}$ & 44.0 & Not included & [66] \\
\hline
\end{tabular}

${ }^{a}$ includes parasitological, pathological (e.g., starvation and gangrenous limb) and bacteriological findings (e.g., Salmonella); ${ }^{\text {b }}$ includes drowning, injury from agricultural or garden tools and fire; ${ }^{\mathrm{c}}$ speculated but not confirmed. 


\section{The Risk of Road Mortality Is Not Equal. Which Are the Risk-Prone Individuals?}

The risk of road mortality over time varies spatially and between individuals in a population [67]. Differential risk is a function of risk per crossing, which largely depends on animal crossing speed, traffic volume and road width, multiplied by the frequency of crossing. This is associated with individual responses to roads and biological characteristics, such as reproductive strategy and pre-hibernation foraging [68]. Individual-based movement patterns cause different exposure to traffic in the environment [41], which has important repercussions for reproductive output [10]. For example, for species such as hedgehogs that have a promiscuous mating system and maternal natal care, adult females have a more important role in population growth than males [69]. Moreover, the frequency distribution of age-at-death in a population is central to life history evolution and population dynamics [10].

No studies have empirically examined the individual-based risk of road mortality over time for hedgehogs, nor the potential variation in carcass detectability or persistence between different age groups. Current knowledge relies on limited data on the sex ratio and age structure of casualties. During a study of E. europaeus over $259.5 \mathrm{~km}$ of road in Ireland, Haigh et al. [42] revealed that $65 \%$ (67 out of 103) of those killed on roads were male. Moreover, Haigh et al. [70] tested several techniques to age hedgehogs, such as dentary bone analysis, jaw and hind foot length. These produced accurate age assessments and identified that the mean age of road-killed hedgehogs was 1.94 years. These findings were similar to those of Goransson et al. [71], who found that $80 \%$ of E. europaeus traffic casualties in Sweden were males who had survived one winter. To understand the significance of sex- and age-specific road mortality to population dynamics, these figures should be considered in the context of the number of individuals in that sex/age class in the wider population. Moreover, it is possible that, due to their small size, juvenile hedgehogs are readily scavenged or not detected during driving surveys.

The majority of hedgehogs are reproductively active in their second year (after one successful hibernation) [54,70]. Although research into the road mortality of different sexes and age groups is sparse, the majority of studies indicate that reproductively active males are most commonly killed on roads. Male hedgehogs have larger home ranges and nightly movements than females [14,72], particularly during the breeding season [73]. This would, all other conditions being equal, increase the number of roads that males must cross each night. Conversely, females are most likely to be involved in traffic collisions in autumn after intensive natal care as their net-movement increases to build fat reserves for hibernation [42]. The removal of reproductively active individuals carries a greater threat to hedgehog population viability because it can skew the age ratio and cause a decline in recruitment [74]. On the one hand, the disproportionate loss of adult males may not be as consequential for population growth as adult female deaths [5]. On the other hand, males are more commonly killed before or during breeding season, unlike females [42]. There is a possibility that fewer males successfully contribute to the gene pool and the relatedness in a population increases over time. If severe enough, this may cause a decrease in population fitness associated with inbreeding depression [75] (see Section 4), although research on the topic remains limited.

\section{The Role of Road Mortality in Fragmentation Effects}

Habitat fragmentation by transport infrastructure and the associated development has become one of the greatest threats to biodiversity [39]. The consequences of road-induced fragmentation for the integrity of natural environments are well-researched [76,77]. Several different, yet not mutually exclusive, mechanisms restrict animal dispersal across roads-lethal road collisions, the avoidance of the road or roadside habitat and the inability to traverse the road or nearby area, such as due to a central median or parallel drainage ditch [78]. Road mortality is likely to act as a filter to movement for many species, rather than an absolute barrier, as animals may be able to make successful journeys across the road, even across large roads and bridges [79]. For hedgehogs, road mortality is considered a more severe restriction to dispersal on smaller roads. For example, E. roumanicus in Bulgaria [33] and 
E. concolor in Turkey [80] were shown to have greater casualty rates on quieter, regional roads than highways. This may result from quieter roads allowing more crossing attempts [58], having fewer physical barriers than major roads and/or their placement in areas with higher hedgehog densities. In severe cases, increased road mortality could lead to death rates exceeding birth rates, which may change a local population to a sink [81].

Road mortality has been shown to be the largest contributor to population fragmentation [81,82], albeit not always [3]. It is possible that physical barriers such as roadside fencing and road avoidance behaviour cause fragmentation via more stringent restrictions to movement. Both barriers and road avoidance behaviour are particularly common on roads with higher traffic volumes and speeds [78]. Dowding et al. [58] reported avoidance of foraging near roads, but not of crossing quieter roads, by E. europaeus. Moreover, Rondinini and Doncaster [83] compared observed E. europaeus movements in Southampton, UK, with "random walks" and identified clear road avoidance behaviour that increased with road width (and associated higher traffic). In corroboration with Rondinini and Doncaster [83], a traffic volume of 3000 vehicles/day (common for busy urban roads) in New Zealand led to the isolation of E. europaeus populations [22].

This combined effect of road mortality and avoidance for fragmentation is readily explained by traffic flow theory, which postulates a positive and asymptotic relationship between traffic volume and roadkill counts. Road mortality will increase with rising traffic volume until reaching an asymptote, when the busy roads (with greater noise levels) form complete barriers and are avoided, or the roads suppress population size and reduce the number of individuals crossing roads [84]. It is clear that roads constitute semi-permeable barriers for hedgehogs and that the extent of fragmentation is context-specific.

\section{Biomolecular Insights into Fragmentation}

Recent advances in genetic approaches have bridged the gap between molecular and road ecology to address the chronic impacts of fragmentation [85]. Insights into the genetic effects of hedgehog population fragmentation have grown since the development of eleven nuclear microsatellite primers (genetic markers) for E. europaeus by Becher and Griffiths [86] and Henderson et al. [87]. The markers have been used to genotype several closely related hedgehog species and can identify genetic similarities between individuals and, therefore, the level of inbreeding [15]. The variability of genetic markers is particularly important for small mammals such as hedgehogs, where fragmentation is likely to act at microspatial scales [88]. Braaker et al. [89] reported that two main rivers and major transport infrastructure (a four-lane highway and railroads) separate three genetic clusters of the E. europaeus population in Zurich. Moreover, combined movement models and microsatellite data indicated that fragmentation and high resistance in the urban matrix of Zurich, predominately from highways, footpaths, buildings and water bodies, contribute to the genetic structure of the hedgehog population at the local level, i.e., within clusters [89]. The weak correlation between genetic structure and geographical distance in several additional hedgehog studies indicates that linear infrastructure restricts gene flow enough to affect genetic heterozygosity $[88,90,91]$. However, the hedgehog's promiscuous mating system and ability for heteropaternal superfecundity (a litter fertilised by different males) may partly counteract the genetic effects of isolation [92]. Inbreeding coefficients would be reduced as a litter can consist of several half-siblings. The reality of this, however, remains untested, and Barthel [93] reported potentially early signs of inbreeding in E. europaeus subpopulations in Berlin. A promising, relatively unused strategy for examining population isolation is genetic pedigree analysis, which uses microsatellites to detect migration rates (e.g., across roads) and local geographies of closely related individuals. This forms a quantitative tool to identify the likelihood of inbreeding and whether the population is acting as a sink population $[76,94]$. 


\section{Potential Road Mitigation Measures for Hedgehog Populations}

As road construction and traffic volumes continue to grow, accommodating the increase in human activity without jeopardising the viability of wild populations remains a major challenge. Approaches for sustainable infrastructure development should tackle both the local (mortality and habitat degradation) and landscape (fragmentation and population viability) impacts of roads, yet there is no simple solution or decision-making framework [11]. A growing number of legal imperatives, such as Article 10 of the European Union's Habitat Directive (92/43/EEC) and the National Environmental Policy Act (1969), as well as international guidelines, such as the United Nations' Sustainable Development Goals, motivate transport planners to safeguard habitat connectivity and ecosystem functioning. This means newer major roads, in particular those built in Central and Eastern Europe, often have integrated wildlife crossings, such as underpasses or overpasses [39]. Minor roads, however, receive less attention despite the majority of road networks consisting of these low-traffic roads [82]. The range of mitigation measures can be classified using four main criteria; road crossing structures, traffic calming measures, habitat management and configuration of the road network [95].

\subsection{Road Crossing Structures}

Exclusionary fencing is a dominant strategy to impede an animal's attempt to cross a road. However, fencing was shown to cause a $30 \%$ reduction in E. europaeus population viability in The Netherlands by intensifying population isolation [96]. Instead, combining fencing with road tunnels or green bridges such as overpasses is widely advocated for many species $[36,97,98]$. This method strives to reduce barrier effects by providing both a reduction in road mortality and conserving or increasing landscape permeability [5]. Several studies have documented varied levels of crossing structure use by E. concolor in Greece [99], E. europaeus in Spain [44,100], Portugal [101], the UK [102,103] and Poland [104,105], and Erinaceinae sp. in Spain [106] (see review by De Vries [107]). This variation of use is likely due, in part, to differences in tunnel design, location and surrounding habitat, suggesting that the uptake of mitigation depends on optimality of species-specific features. For example, hedgehogs have been shown to frequent tunnels with a greater openness ratio (short in length, high and wide) nearer urban areas [101]. Moreover, previous studies demonstrate that hedgehogs avoid areas with predator (badger Meles meles) odour, although the avoidance did not always persist [108,109]. Badgers are known to utilise road tunnels [103], sometimes very regularly, and whether this negatively influences hedgehog use of road mitigation structures remains unknown.

\subsection{Traffic Calming Measures}

Crossing structures are often concentrated at clusters of roadkill [110]. However, this hotspot approach is contentious; several authors propose that a lack of road mortality may signal a previously declined population or a population that exhibits high road avoidance behaviour [111,112]. If so, the necessity for mitigation to assist in population recovery or protection is overlooked. Similarly, the fencing associated with crossing structures could block locations of frequent successful crossings if inappropriately placed. Instead, smaller-scale traffic calming measures that increase driver awareness may be equally effective and substantially cheaper. These aim to enhance preferred crossing sites, which do not necessarily correspond with roadkill hotspots, in order to dissuade the use of riskier crossing locations [7,81]. Traffic calming measures adopted in the past include speed bumps, speed restrictions and warning signs [95]. These initiatives may be particularly effective for hedgehogs given that they frequently attempt to cross quieter roads [58]. Whilst a reduction in speed would be expected to result in a substantial reduction in roadkill [113], the realised effect depends on whether drivers adhere to the speed regulations, which can be difficult to govern [114], and whether, even at a slower speed, a driver can see and avoid a small animal at night. 


\subsection{Habitat Management}

Additional mitigation possibilities include managing roadside habitats by increasing habitat quality, local connectivity [95] and changing road verge management [115]. These improve the core habitat and allow individuals to locate sufficient resources whilst crossing fewer roads. Several authors recommend removing or reducing shrubbery in central medians to reduce road mortality $[116,117]$ (but see [118]). The use of central medians by fauna has not been well-studied and, if they are in fact beneficial to animal movement across a road, their removal may exacerbate barrier effects [78]. Modifying hedgerows, which act as conduits of hedgehog movements, near roads is also likely to be an important action. For example, Huijser [53] identified that, out of 942 traffic victims, 20-27\% and 140\% more E. europaeus road casualties were found in areas where hedgerows and railroads, respectively, were perpendicular to roads rather than parallel. Therefore, how roads and local landscape features are orientated in relation to one another warrants consideration.

\subsection{Road Configuration}

In Western Europe, many major roads were built more than 40 years ago with little consideration for wildlife [37]. Retrofitting crossing structures can be an expensive undertaking, and their construction is often logistically challenging [119]. It is therefore essential to consider how landscape configuration can be designed to meet the needs of human settlements, associated road systems and habitat networks simultaneously [120]. Previous multispecies simulation studies have reported that road mortality rates and population persistence were improved when traffic volume was concentrated on fewer roads [121,122]. Surprisingly, van Strien and Grêt-Regamey [119] reported opposite results for hedgehogs. These studies reinforce the significance of whole landscape planning; the high rates of new road development in Central and Eastern Europe provide the opportunity to consider road configuration and maintain suitable habitat matrices for E. roumanicus and E. concolor $[17,49]$.

\section{Current Knowledge Gaps and Future Directions}

Major impediments to furthering knowledge on hedgehog road ecology are the high labour and monetary costs linked to collecting relevant data for at least one population - that is, road casualty rates, movement and population structure data (and optionally genetic information). Moreover, although GPS devices are increasingly utilised for movement studies [10,123], including for hedgehogs [89,93], the high initial costs often reduce sample sizes and lead to results with poor statistical inference (see [124] for full review). Understanding the ramifications of hedgehog road mortality is further hindered by the lack of basic biological and ecological knowledge on some species such as E. concolor, as well as uncertain rigor of population and road casualty estimations for other species. Current population estimates are from citizen science surveys and extrapolations of presence-only density estimates in different habitat types $[125,126]$. The assumptions associated with these methods make estimates of population size equivocal [19]. Improved population estimates are critical to validate existing findings and could be achieved by large-scale collaborations or more standardised citizen science, such as using camera traps and random encounter methods $[127,128]$. Moreover, roadkill estimates of many species are likely to be underestimated due to scavengers removing carcasses and varying carcass detectability due to factors such as carcass decay, the driver's speed and the animal's body size [81,129]. As a result, raw carcass data must be corrected for carcass persistence and detection probability to obtain accurate estimates of the number of animals killed on roads, as demonstrated by Péron et al. [130] and Santos et al. [52]. Similarly, it is likely that a small proportion of hedgehog-vehicle collisions do not result in instantaneous death and that a hedgehog's delayed traffic-induced death off the road is not counted. The possible role of wildlife hospitals in affecting estimates of mortality rates and genetic fragmentation is also important to consider. Particularly common for E. europaeus in Western Europe, wildlife rehabilitators care for and release injured hedgehogs that would otherwise die [64]. While this 
is undoubtedly valuable for the species' conservation, future road ecology analyses must consider confounding factors such as these.

Of particular significance is that studies seldom examine road mortality in the context of a population's intrinsic growth rate. Considering growth rates reveals less of a "snapshot" of mortality and determines whether populations can sustain current and future road casualty rates. Future research should explicitly model the sensitivity of population growth curves to sex- and age-specific road mortality, using methods such as population viability models and elasticity analysis [41]. Population modelling could be further used on existing data sets, such as from nationwide citizen science projects, to accurately estimate yearly road mortality or, for populations with both road mortality and density estimates, an estimate of local demographic compensation. Another informed approach could incorporate population density, the sex and age of casualties and other sources of mortality into the framework of compensation-additive mortality [131]. This explores whether road mortality is compensatory and removes the already "doomed surplus" in a population or is additive by increasing total mortality [55]. For example, if road-killed individuals have a poor body condition (e.g., they are affected by parasites or other diseases), the severity of road mortality is reduced as their likelihood of long-term survival is low regardless of traffic [43].

The efficacy of road mitigation measures for wildlife is rarely tested; this poses significant constraints on justifying mitigation efforts and adapting strategies for maximum benefit. Many studies are either too short or adopt study designs that cannot demonstrate causality to population viability, such as gene flow or lasting reductions in road mortality [132]. In the future, studies should employ long-term monitoring of mitigation measures and before-and-after-control-impact (BACI) or control-impact experimental designs, where possible. These studies allow for changes in the investigated population parameters, such as density, sex ratio or genetic diversity, to be soundly attributed to the mitigation measures [133]. Future research should also present more holistic mitigation recommendations by examining socioeconomic factors such as vehicle and pedestrian travel efficiency [119] and the cost-effectiveness of strategies [98] (Table 3). The challenge of accommodating both hedgehog and anthropogenic demands on the landscape highlights the crucial role of interdisciplinary and collective thinking in road ecology [11]. 
Table 3. Summary of published findings, as well as gaps in the literature and recommendations for future research as discussed in this review.

\begin{tabular}{|c|c|c|}
\hline Published Findings & Gaps in Understanding as Revealed by This Review & $\begin{array}{c}\text { Directions for Future Research as Recommended by } \\
\text { This Review }\end{array}$ \\
\hline $\begin{array}{l}\text { Traffic collisions may cause an annual loss of } \\
3-24 \% \text { of a local hedgehog population, and 9-30\% } \\
\text { of a nationwide population }[19,46,53,54] \text {. } \\
\text { Road mortality is consistently in the top three } \\
\text { contributors to total mortality }[40,60,61] \text {. }\end{array}$ & $\begin{array}{l}\text { - The accuracy of current local and total } \\
\text { population estimates. } \\
\text { Whether populations can compensate for road } \\
\text { mortality with increased survival and/or fecundity. }\end{array}$ & $\begin{array}{l}\text { Establishing standardised surveys for improved } \\
\text { population estimates. } \\
\text { Long-term population studies to evaluate road } \\
\text { mortality in the context of population growth. }\end{array}$ \\
\hline $\begin{array}{l}\text { - Hedgehog roadkill is disproportionately clustered } \\
\text { in suburban areas and consists predominately of } \\
\text { males and adults }[28,30,39,68] \text {. }\end{array}$ & $\begin{array}{l}\text { - Whether carcass detectability and persistence vary } \\
\text { between age groups. } \\
\text { How road and habitat characteristics influence } \\
\text { road mortality risks between demographic groups } \\
\text { over time. }\end{array}$ & $\begin{array}{l}\text { - Studies into the road crossing behaviour of } \\
\text { different demographic groups. } \\
\text { Evaluating the consequences of sex- and } \\
\text { age-specific road mortality on hedgehog } \\
\text { population trends. }\end{array}$ \\
\hline $\begin{array}{l}\text { - Hedgehog populations appear particularly } \\
\text { vulnerable to fragmentation effects }[30,81] \text {. } \\
\text { Hedgehog populations exhibit distinct genetic } \\
\text { substructure, often in relation to linear } \\
\text { infrastructure }[86,90,91] .\end{array}$ & $\begin{array}{l}\text { - Whether the hedgehog's promiscuity and } \\
\text { heteropaternal superfecundity can lessen the } \\
\text { impacts of isolation on genetic structure. }\end{array}$ & $\begin{array}{l}\text { Establishing isolation effects from roads, such as } \\
\text { using inbreeding coefficients or genetic } \\
\text { pedigree analysis. }\end{array}$ \\
\hline $\begin{array}{l}\text { Exclusionary fences alone are not an appropriate } \\
\text { mitigation measure for hedgehog road } \\
\text { mortality [96]. } \\
\text { - Hedgehogs infrequently use crossing } \\
\text { structures }[96,98,101] \text {. }\end{array}$ & $\begin{array}{l}\text { - The population-level responses to } \\
\text { mitigation measures. } \\
\text { Whether the use of crossing structures by badgers } \\
\text { impacts their efficacy for hedgehogs. } \\
\text { - Whether traffic-calming methods are an effective } \\
\text { and cheaper option for road mitigation. }\end{array}$ & $\begin{array}{l}\text { - Quantification of population viability in relation to } \\
\text { mitigation using BACI or control/impact studies, } \\
\text { such as using roadkill counts, population density } \\
\text { and gene flow. } \\
\text { Integration of ecological and socioeconomic } \\
\text { perspectives on road mitigation and construction. }\end{array}$ \\
\hline
\end{tabular}




\section{Conclusions}

As hedgehogs remain a prominent victim of WVCs and road infrastructure continues to expand in Europe [38,39], evaluating whether hedgehog populations are vulnerable to the long-term negative impacts of roads is urgently needed. The literature presents several evaluative criteria for this purpose, including proportional loss, differential risk between demographic groups and the fecundity of the remaining population. Previous studies are in general agreement that adult males are more prone to road mortality and that hedgehog-vehicle collisions can disrupt population dynamics, for example, by fragmentation. However, barriers exist to understanding whether this translates to population decline and to disentangling the relative impact of road mortality on population viability compared to other factors. These difficulties remain the primary challenges for hedgehog conservation throughout Europe. Future research should prioritise the inclusion of sex- and age-specific fecundity and survival rates in population models and analyses. This review highlights the importance of long-term monitoring and robust experimental design such as BACI for effective decision-making by conservation practitioners and policy makers. Moreover, considerations of wildlife must be integrated into the early planning stages of road construction to meet the goals of sustainable development. Collaboration between ecologists, engineers and spatial planners is not only good practice, but likely to be indispensable in achieving a reduction in the conflict for space that characterises the 21st century.

Author Contributions: Conceptualisation, L.J.M. and R.W.Y.; writing-original draft preparation, L.J.M.; writing-review and editing, L.J.M., S.O.P., P.J.B., A.J.B., H.L.H., S.E.P. and R.W.Y.; supervision, S.O.P., P.J.B., A.J.B., H.L.H., S.E.P. and R.W.Y.; funding acquisition, R.W.Y. All authors have read and agreed to the published version of the manuscript.

Funding: This research was funded by the People's Trust for Endangered Species and Nottingham Trent University.

Acknowledgments: We would like to thank the two anonymous reviewers for their insightful comments that greatly improved this manuscript.

Conflicts of Interest: The authors declare no conflict of interest. The funders had no role in the conceptualisation or writing of the manuscript.

\section{References}

1. Ibisch, P.L.; Hoffmann, M.T.; Kreft, S.; Pe'Er, G.; Kati, V.; Biber-Freudenberger, L.; DellaSala, D.A.; Vale, M.M.; Hobson, P.R.; Selva, N. A global map of roadless areas and their conservation status. Science 2020, 80, 1423-1427. [CrossRef] [PubMed]

2. Meijer, J.R.; Huijbregts, M.A.J.; Schotten, K.C.G.J.; Schipper, A.M. Global patterns of current and future road infrastructure. Environ. Res. Lett. 2018, 13, 6. [CrossRef]

3. Forman, R.T.T.; Alexander, L.E. Roads and their major ecological effects. Ann. Rev. Ecol. Syst. 1998, 29, 207-231. [CrossRef]

4. Coffin, A.W. From roadkill to road ecology: A review of the ecological effects of roads. J. Transp. Geogr. 2007, 15, 396-406. [CrossRef]

5. Seiler, A.; Helldin, J.O. Mortality in wildlife due to transportation. In The Ecology of Transportation: Managing Mobility for the Environment; Davenport, J., Davenport, J.L., Eds.; Springer: New York, NY, USA, 2006; pp. 165-189.

6. Morelle, K.; Lehaire, F.; Lejeune, P. Spatio-temporal patterns of wildlife-vehicle collisions in a region with a high-density road network. Nat. Conserv. 2013, 5, 53-73. [CrossRef]

7. Meek, R. Patterns of reptile road-kills in the Vendée region of western France. Herpetol. J. 2009, 19, $135-142$.

8. Huijser, M.P.; Bergers, P.J.M. The effect of roads and traffic on hedgehog (Erinaceus europaeus) populations. Biol. Conserv. 2000, 95, 111-116. [CrossRef]

9. Fahrig, L.; Rytwinski, T. Effects of roads on animal abundance: An empirical review and synthesis. Ecol. Soc. 2009, 14, 1. [CrossRef]

10. Dexter, C.E.; Appleby, R.G.; Scott, J.; Edgar, J.P.; Jones, D.N. Individuals matter: Predicting koala road crossing behaviour in south-east Queensland. Aust. Mammal. 2018, 40, 67-75. [CrossRef] 
11. Trombulak, S.C.; Frissell, C.A. Review of ecological effects of roads on terrestrial and aquatic communities. Conserv. Biol. 2000, 14, 18-30. [CrossRef]

12. Carvalho, F.; Mira, A. Comparing annual vertebrate road kills over two time periods, 9 years apart: A case study in Mediterranean farmland. Eur. J. Wildl. Res. 2011, 57, 157-174. [CrossRef]

13. Bannikova, A.; Lebedev, V.; Abramov, A.; Rozhnov, V. Contrasting evolutionary history of hedgehogs and gymnures (Mammalia: Erinaceomorpha) as inferred from a multigene study. Biol. J. Linn. Soc. 2014, 112, 499-519. [CrossRef]

14. García-rodríguez, S.; Puig-montserrat, X. Algerian hedgehog (Atelerix algirus Lereboullet, 1842) habitat selection at the northern limit of its range. Galemys 2014, 26, 49-56. [CrossRef]

15. Bolfíková, B.; Hulva, P. Microevolution of sympatry: Landscape genetics of hedgehogs Erinaceus europaeus and E. roumanicus in Central Europe. Heredity 2012, 108, 248-255. [CrossRef]

16. Huijser, M.P.; Bergers, P.J.M.; De Vries, J.G. Hedgehog traffic victims: How to quantify effects on the population level and the prospects for mitigation. In Proceedings of the International Conference on Wildlife Ecology and Transportation, Fort Myers, FL, USA, 9-12 February 1998; Evink, G., Garrett, P., Zeigler, D., Berry, J., Eds.; Florida Department of Transportation: Tallahassee, FL, USA, 1998.

17. Gruychev, G.V. Animal road mortality (Aves \& Mammalia) from the new section of the Maritsa Highway (South Bulgaria). Ecol. Balk. 2018, 10, 11-18.

18. Tejera, G.; Rodríguez, B.; Armas, C.; Rodríguez, A. Wildlife-vehicle collisions in Lanzarote Biosphere Reserve, Canary Islands. PLoS ONE 2018, 13, e0192731. [CrossRef] [PubMed]

19. Wembridge, D.E.; Newman, M.R.; Bright, P.W.; Morris, P.A. An estimate of the annual number of hedgehog (Erinaceus europaeus) road casualties in Great Britain. Mammal. Commun. 2016, 2, 8-14.

20. Huijser, M.P.; Bergers, P.J.M. The mortality rate in a hedgehog (Erinaceus europaeus) population: The relative importance of road kills. In Habitat Fragmentation E Infrastructure, Proceedings of the International Conference on Habitat Fragmentation, Infrastructure and the Role of Ecological Engineering, Maastricht, The Netherlands, 18-21 September 1995; Canters, K., Ed.; Ministry of Transport, Public Works and Water Management: The Hague, The Netherlands, 1997; pp. 98-104.

21. Holsbeek, L.; Rodts, J.; Muyldermans, S. Hedgehog and other animal traffic victims in Belgium: Results of a countryside survey. Lutra 1999, 42, 111-119.

22. Brockie, R.E.; Sadleir, R.M.F.S.; Linklater, W.L. Long-term wildlife road-kill counts in New Zealand. N. Z. J. Zool. 2009, 36, 123-134. [CrossRef]

23. Schwartz, A.L.W.; Shilling, F.M.; Perkins, S.E. The value of monitoring wildlife roadkill. Eur. J. Wildl. Res. 2020, 66, 18. [CrossRef]

24. Reichholf, J.H. Starker Rückgang der Häufigkeit überfahrener Igel Erinaceus europaeus in Südostbayern und seine Ursachen. Mitteilungen der Zool Gesellschaft Braunau 2015, 113, 309-314.

25. Müller, F. Langzeit-Monitoring der Strassenverkehrsopfer beim Igel (Erinaceus europaeus L.) zur Indikation von Populationsdichteveränderungen entlang zweier Teststrecken im Landkreis Fulda. Beiträge zur Naturkd Osthessen 2018, 54, 21-26.

26. Wilson, E.; Wembridge, D.E. The State of Britain's Hedgehogs 2018; The People's Trust for Endangered Species: London, UK, 2018.

27. Hof, A.R.; Bright, P.W. Quantifying the long-term decline of the West European hedgehog in England by subsampling citizen-science datasets. Eur. J. Wildl. Res. 2016, 62, 407-413. [CrossRef]

28. Pettett, C.E.; Johnson, P.J.; Moorhouse, T.P.; Macdonald, D.W. National predictors of hedgehog Erinaceus europaeus distribution and decline in Britain. Mamm. Rev. 2018, 48, 1-6. [CrossRef]

29. Roos, S.; Johnston, A.; Noble, D. UK Hedgehog Datasets and Their Potential for Long-Term Monitoring; The British Trust of Ornithology: Norfolk, UK, 2012.

30. Van de Poel, J.L.; Dekker, J.; van Langevelde, F. Dutch hedgehogs Erinaceus europaeus are nowadays mainly found in urban areas, possibly due to the negative effects of badgers Meles meles. Wildl. Biol. 2015, 21, 51-55. [CrossRef]

31. Krange, M. Change in the Occurrence of the West European Hedgehog (Erinaceus europaeus) in Western Sweden during 1950-2010. Master's Thesis, University of Karlstad, Karlstad, Sweden, 2015.

32. Wright, P.G.R.; Coomber, F.G.; Bellamy, C.C.; Perkins, S.E.; Mathews, F. Predicting hedgehog mortality risks on British roads using habitat suitability modelling. PeerJ 2020, 7, e8154. [CrossRef] 
33. Bil, M.; Heigl, F.; Janoska, Z.; Vercayie, D.; Perkins, S.E. Benefits and challenges of collaborating with volunteers: Examples from National wildlife roadkill reporting systems in Europe. J. Nat. Conserv. 2020, 54, 125798. [CrossRef]

34. George, L.; Macpherson, J.L.; Balmforth, Z.; Bright, P.W. Using the dead to monitor the living: Can road kill counts detect trends in mammal abundance? Appl. Ecol. Environ. Res. 2011, 9, 27-41. [CrossRef]

35. Baker, P.J.; Harris, S.; Robertson, C.P.J.; Saunders, G.; White, P.C.L. Is it possible to monitor mammal population changes from counts of road traffic casualties? An analysis using Bristol's red foxes Vulpes vulpes as an example. Mamm. Rev. 2004, 34, 115-130. [CrossRef]

36. Van der Ree, R.; Heinze, D.; Mccarthy, M.; Mansergh, I. Wildlife tunnel enhances population viability. Ecol. Soc. 2009, 14, 7-15. [CrossRef]

37. Selva, N.; Kreft, S.; Kati, V.; Schluck, M.; Jonsson, B.-G.; Mihok, B.; Okarma, H.; Ibisch, P.L. Roadless and low-traffic areas as conservation targets in Europe. Environ. Manag. 2011, 48, 865-877. [CrossRef] [PubMed]

38. Department of Transport UK. Road Traffic Forecasts 2018: Moving Britain Ahead. 2018. Available online: https://assets.publishing.service.gov.uk/government/uploads/system/uploads/attachment_data/file/ 740399/road-traffic-forecasts-2018.pdf (accessed on 29 March 2020).

39. Dom, A.; De Ridder, W. Paving the Way for EU Enlargement; European Environment Agency: Copenhagen, Denmark, 2002.

40. Bonnet, X.; Naulleau, G.; Shine, R. The dangers of leaving home: Dispersal and mortality in snakes. Biol. Conserv. 1999, 89, 39-50. [CrossRef]

41. Row, J.R.; Blouin-Demers, G.; Weatherhead, P.J. Demographic effects of road mortality in black ratsnakes (Elaphe obsoleta). Biol. Conserv. 2007, 137, 117-124. [CrossRef]

42. Haigh, A.; O'Riordan, R.M.; Butler, F. Hedgehog Erinaceus europaeus mortality on Irish roads. Wildl. Biol. 2014, 20, 155-160. [CrossRef]

43. Rautio, A.; Isomursu, M.; Valtonen, A.; Hirvelä-Koski, V.; Kunnasranta, M. Mortality, diseases and diet of European hedgehogs (Erinaceus europaeus) in an urban environment in Finland. Mammal. Res. 2016, 61, 161-169. [CrossRef]

44. Puig, J.; Sanz, L. Wildlife roadkills and underpass use in Northern Spain. Environ. Eng. Manag. J. 2012, 11, 1141-1147. [CrossRef]

45. Hell, P.; Plavý, R.; Slamečka, J.; Gašparík, J. Losses of mammals (Mammalia) and birds (Aves) on roads in the Slovak part of the Danube Basin. Eur. J. Wildl. Res. 2005, 51, 35-40. [CrossRef]

46. Orłowski, G.; Nowak, L. Road mortality of hedgehogs Erinaceus spp. in farmland in lower Silesia (south-western Poland). Pol. J. Ecol. 2004, 52, 377-382.

47. Mikov, A.M.; Georgiev, D.G. On the road mortality of the northern white-breasted hedgehog (Erinaceus roumanicus Barrett-Hamilton, 1900) in Bulgaria. Ecol. Balk. 2018, 10, 19-23.

48. Пархоменко, В. Загибель ссавців на автошляхах північно-східної України (In English: Death of mammals on the roads of northeastern Ukraine). Proc. Theriol. Sch. 2017, 15, 139-149.

49. Bitušík, P.; Kocianová-adamcová, M.; Brabec, J.; Malina, R.; Tesák, J.; Urban, P. The effects of landscape structure and road topography on mortality of mammals: A case study of two different road types in Central Slovakia. Lynx 2017, 48, 39-51. [CrossRef]

50. Загороднюк, I. Загибель тварин на дорогах: Оцінка впливуавтотранспорту на популяції диких і свійських тварин (In English: Mortality of animals on roads: Assessment of vehicle traffic's influence at populations of wild and domestic animals.). Proc. Theriol. Sch. 2006, 8, 120-125.

51. Santos, S.M.; Carvalho, F.; Mira, A. How long do the dead survive on the road? Carcass persistence probability and implications for road-kill monitoring surveys. PLoS ONE 2011, 6, e25383. [CrossRef] [PubMed]

52. Santos, R.A.L.; Santos, S.M.; Santos-Reis, M.; Picanço de Figueiredo, A.; Bager, A.; Aguiar, L.M.S.; Ascensão, F. Carcass persistence and detectability: Reducing the uncertainty surrounding wildlife-vehicle collision surveys. PLoS ONE 2016, 11, e0165608. [CrossRef] [PubMed]

53. Huijser, M.P. Life on the Edge. Hedgehog Traffic Victims and Mitigation Strategies in an Anthropogenic Landscape. Ph.D. Thesis, Wageningen University, Wageningen, The Netherlands, 2000.

54. Kristiansson, H. Population variables and causes of mortality in a hedgehog (Erinaceus europaeus) population in southern Sweden. J. Zool. 1990, 220, 391-404. [CrossRef]

55. Seiler, A. The Toll of the Automobile: Wildlife and Roads in Sweden. Ph.D. Thesis, Swedish University of Agricultural Sciences, Uppsala, Sweden, 2003. 
56. Reeve, N.J.; Huijser, M.P. Wildlife rescue centre records as a means of monitoring relative change in mortality factors affecting hedgehogs (Erinaceus europaeus). Lutra 1999, 42, 7-24.

57. Sutherland, W.J. Sustainable exploitation: A review of principles and methods. Wildl. Biol. 2001, 7, 131-140. [CrossRef]

58. Dowding, C.V.; Harris, S.; Poulton, S.; Baker, P.J. Nocturnal ranging behaviour of urban hedgehogs, Erinaceus europaeus, in relation to risk and reward. Anim. Behav. 2010, 80, 13-21. [CrossRef]

59. Hof, A.R.; Allen, A.M.; Bright, P.W. Investigating the role of the eurasian badger (Meles meles) in the nationwide distribution of the western european hedgehog (Erinaceus europaeus) in England. Animals 2019, 9, 759. [CrossRef]

60. Hubert, P.; Julliard, R.; Biagianti, S.; Poulle, M.L. Ecological factors driving the higher hedgehog (Erinaceus europeaus) density in an urban area compared to the adjacent rural area. Landsc. Urban. Plan. 2011, 103, 34-43. [CrossRef]

61. Dickman, C.R. Age-related dietary change in the European hedgehog, Erinaceus europaeus. J. Zool. 1988, 215, 1-14. [CrossRef]

62. Reeve, N.J. A Field Study of the Hedgehog (Erinaceus europaeus) with Particular Reference to Movements and Behaviour. Ph.D. Thesis, Royal Holloway University of London, London, UK, 1981.

63. Doncaster, C.P. Testing the role of intraguild predation in regulating hedgehog populations. Proc. R. Soc. $B$ Biol. Sci. 1992, 249, 1324.

64. Yarnell, R.W.; Surgey, J.; Grogan, A.; Thompson, R.; Davies, K.; Kimbrough, C.; Scott, D.M. Should rehabilitated hedgehogs be released in winter? A comparison of survival, nest use and weight change in wild and rescued animals. Eur. J. Wildl. Res. 2019, 65, 6. [CrossRef]

65. Reeve, N.J. The survival and welfare of hedgehogs (Erinaceus europaeus) after release back into the wildlife. Anim. Welf. 1998, 7, 189-202.

66. Rasmussen, S.L.; Berg, T.B.; Dabelsteen, T.; Jones, O.R. The ecology of suburban juvenile European hedgehogs (Erinaceus europaeus) in Denmark. Ecol. Evol. 2019, 9, 13174-13187. [CrossRef]

67. Aresco, M.J. The effect of sex-specific terrestrial movements and roads on the sex ratio of freshwater turtles. Biol. Conserv. 2005, 123, 37-44. [CrossRef]

68. Hels, T.; Buchwald, E. The effect of road kills on amphibian populations. Biol. Conserv. 2001, 99, 331-340. [CrossRef]

69. Rautio, A.; Valtonen, A.; Auttila, M.; Kunnasranta, M. Nesting patterns of European hedgehogs (Erinaceus europaeus) under northern conditions. Acta Theriol. 2014, 59, 173-181. [CrossRef]

70. Haigh, A.; Kelly, M.; Butler, F.; O'Riordan, R.M. Non-invasive methods of separating hedgehog (Erinaceus europaeus) age classes and an investigation into the age structure of road kill. Acta Theriol. 2014, 59, 165-171. [CrossRef]

71. Goransson, G.; Karlsson, J.L. Road mortality of the hedgehog Erinaceus europaeus in southern Sweden. Fauna Flora 1976, 71, 1-6.

72. Glasby, L.; Yarnell, R.W. Evaluation of the performance and accuracy of Global Positioning System bug transmitters deployed on a small mammal. Eur. J. Wildl. Res. 2013, 59, 915-919. [CrossRef]

73. Rautio, A.; Valtonen, A.; Kunnasranta, M. The effects of sex and season on home range in European hedgehogs at the northern edge of the species range. Ann. Zool. Fenn. 2013, 50, 107-123. [CrossRef]

74. Marchand, M.N.; Litvaitis, J.A. Effects of habitat features and landscape composition on the population structure of a common aquatic turtle in a legion undergoing rapid development. Conserv. Biol. 2004, 18, 758-767. [CrossRef]

75. Jaeger, J.A.G.; Bowman, J.; Brennan, J.; Fahrig, L.; Bert, D.; Bouchard, J.; Charbonneau, N.; Frank, K.; Gruber, B.; Tluk von Toschanowitz, K. Predicting when animal populations are at risk from roads: An interactive model of road avoidance behavior. Ecol. Model. 2005, 185, 329-348. [CrossRef]

76. Kormann, U.; Gugerli, F.; Ray, N.; Excoffier, L.; Bollmann, K. Parsimony-based pedigree analysis and individual-based landscape genetics suggest topography to restrict dispersal and connectivity in the endangered capercaillie. Biol. Conserv. 2012, 152, 241-252. [CrossRef]

77. Cullen, L.; Stanton, J.C.; Lima, F.; Uezu, A.; Perilli, M.L.L.; Akcakaya, H.R. Implications of fine-grained habitat fragmentation and road mortality for jaguar conservation in the Atlantic forest, Brazil. PLoS ONE 2016, 11, e0167372. [CrossRef] 
78. Plante, J.; Jaeger, J.A.G.; Desrochers, A. How do landscape context and fences influence roadkill locations of small and medium-sized mammals? J. Environ. Manag. 2019, 235, 511-520. [CrossRef] [PubMed]

79. Bontadina, F. Straßenüberquerungen von Igeln (Erinaceus europaeus). Ph.D. Thesis, University of Zurich, Zurich, Switzerland, 1991.

80. Özcan, A.U.; Özkazanç, N.K. Identifying the hotspots of wildlife-vehicle collision on the Çankırı-kırıkkale highway during summer. Turk. J. Zool. 2017, 41, 722-730. [CrossRef]

81. Grilo, C.; Sousa, J.; Ascensão, F.; Matos, H.; Leitão, I.; Pinheiro, P.; Costa, M.; Bernardo, J.; Reto, D.; Lourenço, R.; et al. Individual spatial responses towards roads: Implications for mortality risk. PLoS ONE 2012, 7, e43811. [CrossRef]

82. Jackson, N.D.; Fahrig, L. Relative effects of road mortality and decreased connectivity on population genetic diversity. Biol. Conserv. 2011, 144, 3143-3148. [CrossRef]

83. Rondinini, C.; Doncaster, C.P. Roads as barriers to movement for hedgehogs. Funct. Ecol. 2002, 16, 504-509. [CrossRef]

84. Van Langevelde, F.; Jaarsma, C.F. Using traffic flow theory to model traffic mortality in mammals. Landsc. Ecol. 2005, 19, 895-907. [CrossRef]

85. Balkenhol, N.; Waits, L.P. Molecular road ecology: Exploring the potential of genetics for investigating transportation impacts on wildlife. Mol. Ecol. 2009, 18, 4151-4164. [CrossRef] [PubMed]

86. Becher, S.A.; Griffiths, R. Isolation and characterization of six polymorphic microsatellite loci in the European hedgehog Erinaceus europaeus. Mol. Ecol. 1997, 6, 89-90. [CrossRef] [PubMed]

87. Henderson, M.; Becher, S.A.; Doncaster, C.P.; Maclean, N. Five new polymorphic microsatellite loci in the European hedgehog Erinaceus europaeus. Mol. Ecol. 2000, 9, 1932-1934. [CrossRef] [PubMed]

88. Becher, S.A.; Griffiths, R. Genetic differentiation among local populations of the European hedgehog (Erinaceus europaeus) in mosaic habitats. Mol. Ecol. 1998, 7, 1599-1604. [CrossRef] [PubMed]

89. Braaker, S.; Kormann, U.; Bontadina, F.; Obrist, M.K. Prediction of genetic connectivity in urban ecosystems by combining detailed movement data, genetic data and multi-path modelling. Landsc. Urban. Plan. 2017, 160, 107-114. [CrossRef]

90. Rasmussen, S.; Nielsen, J.; Jones, O.R.; Berg, T.B.; Pertoldi, C. Genetic structure of the European hedgehog (Erinaceus europaeus) in Denmark. PLoS ONE 2020, 15, e0227205. [CrossRef]

91. Curto, M.; Winter, S.; Seiter, A.; Schmid, L.; Scheicher, K.; Barthel, L.M.F.; Plass, J.; Meimberg, H. Application of a SSR-GBS marker system on investigation of European hedgehog species and their hybrid zone dynamics. Ecol. Evol. 2019, 9, 2814-2832. [CrossRef]

92. Moran, S.; Turner, P.D.; O’Reilly, C. Multiple paternity in the European hedgehog. J. Zool. 2009, 278, 349-353. [CrossRef]

93. Barthel, L.M.F. Population Structure and Behaviour of the European Hedgehog in an Urbanized World. Ph.D. Thesis, Freie Universität, Berlin, Germany, 2019.

94. Proctor, M.F.; Kasworm, W.F.; Teisberg, J.E.; Servhen, J.E.; Radandt, T.G.; Lamb, C.T.; Kendall, K.C.; Mace, R.D.; Paetkau, D.; Boyce, M.S. American black bear population fragmentation detected with pedigrees in the transborder Canada-United States region. Ursus 2020, 31, 1-15. [CrossRef]

95. Lin, S.C. Landscape and traffic factors affecting animal road mortality. J. Environ. Eng. Landsc. Manag. 2016, 24, 10-20. [CrossRef]

96. Bergers, P.J.M.; Nieuwenhuizen, W. Viability of hedgehog populations in central Netherlands. Lutra 1999, 42, 65-75.

97. Clevenger, A.P.; Waltho, N. Factors influencing the effectiveness of wildlife underpasses in Banff National Park. Cons. Biol. 2010, 14, 47-56. [CrossRef]

98. Helldin, J.O.; Petrovan, S.O. Effectiveness of small road tunnels and fences in reducing amphibian roadkill and barrier effects at retrofitted roads in Sweden. PeerJ 2019, 7, e7518. [CrossRef] [PubMed]

99. Tritsis, K.M. Assessment of the Use of Crossing Structures by Mammals along Egnatia Motorway in Northern Greece. Master's Thesis, University of Kiel, Kiel, Greece, 2011.

100. Mata, C.; Hervás, I.; Herranz, J.; Suárez, F.; Malo, J. Are motorway wildlife passages worth building? Vertebrate use of road-crossing structures on a Spanish motorway. J. Environ. Manag. 2008, 88, 407-415. [CrossRef]

101. Ascensão, F.; Mira, A. Factors affecting culvert use by vertebrates along two stretches of road in southern Portugal. Ecol. Res. 2007, 22, 57-66. [CrossRef] 
102. Jarvis, L.E.; Hartup, M.; Petrovan, S.O. Road mitigation using tunnels and fences promotes site connectivity and population expansion for a protected amphibian. Eur. J. Wildl. Res. 2019, 65, 27. [CrossRef]

103. Eldridge, B.; Wynn, J. Use of badger tunnels by mammals on highways agency schemes in England. Conserv. Evid. 2011, 8, 53-57.

104. Ważna, A.; Kaźmierczak, A.; Cichocki, J.; Bojarski, J.; Gabryś, G. Use of underpasses by animals on a fenced expressway in a suburban area in western Poland. Nat. Conserv. 2020, 39, 1-18. [CrossRef]

105. Myslajek, R.W.; Nowak, S.; Kurek, K.; Tolkacz, K.; Gewartowska, O. Utilisation of a wide underpass by mammals on an expressway in the Western Carpathians, S Poland. Folia Zool. 2016, 65, 225-232. [CrossRef]

106. Yanes, M.; Velasco, J.M.; Suárez, F. Permeability of roads and railways to vertebrates: The importance of culverts. Biol. Conserv. 1995, 71, 217-222. [CrossRef]

107. De Vries, J.G. Hedgehogs on the road: From research to practice. Lutra 1999, 42, 99-110.

108. Ward, J.F.; Macdonald, D.W.; Doncaster, C.P. Responses of foraging hedgehogs to badger odour. Anim. Behav. 1997, 53, 709-720. [CrossRef]

109. Doncaster, C.P. Can badgers affect the use of tunnels by hedgehogs? A review of the literature. Lutra 1999, 42, 59-64.

110. Clevenger, A.; Waltho, N. Performance indices to identify attributes of highway crossing structures facilitating movement of large mammals. Biol. Conserv. 2005, 121, 453-464. [CrossRef]

111. Eberhardt, E.; Mitchell, S.; Fahrig, L. Road kill hotspots do not effectively indicate mitigation locations when past road kill has depressed populations. J. Wildl. Manag. 2013, 77, 1353-1359. [CrossRef]

112. Ascensão, F.; Kindel, A.; Teixeira, F.Z.; Barrientos, R.; D’Amico, M.; Borda-de-Água, L.; Pereira, H.M. Beware that the lack of wildlife mortality records can mask a serious impact of linear infrastructures. Glob. Ecol. Conserv 2019, 19, e00661.

113. Hobday, A.J.; Minstrell, M.L. Distribution and abundance of roadkill on Tasmanian highways: Human management options. Wildl. Res. 2008, 35, 712-726. [CrossRef]

114. Dique, D.S.; Thompson, J.; Preece, H.J.; Penfold, G.C.; de Villiers, D.L.; Leslie, R.S. Koala mortality on roads in south-east Queensland: The koala speed-zone trial. Wildl. Res. 2003, 30, 419-426. [CrossRef]

115. Clevenger, A.P.; Chruszcz, B.; Gunson, K.E. Spatial patterns and factors influencing small vertebrate fauna road-kill aggregations. Biol. Conserv. 2002, 109, 15-26. [CrossRef]

116. Boves, T.J.; Belthoff, J.R. Roadway mortality of barn owls in Idaho, USA. J. Wildl. Manag. 2012, 76, 1381-1392. [CrossRef]

117. Clevenger, A.P.; Kociolek, A.V. Potential impacts of highway median barriers on wildlife: State of the practice and gap analysis. Environ. Manag. 2013, 52, 1299-1312. [CrossRef] [PubMed]

118. Canal, D.; Camacho, C.; Martín, B.; de Lucas, M.; Ferrer, M. Fine-scale determinants of vertebrate roadkills across a biodiversity hotspot in Southern Spain. Biodivers. Conserv. 2019, 28, 3239-3256. [CrossRef]

119. Van Strien, M.J.; Grêt-Regamey, A. How is habitat connectivity affected by settlement and road network configurations? Results from simulating coupled habitat and human networks. Ecol. Modell. 2016, 342, 186-198. [CrossRef]

120. Van der Ree, R.; Jaeger, J.A.G.; van der Grift, E.A.; Clevenger, A.P. Effects of roads and traffic on wildlife populations and landscape function: Road ecology is moving toward larger scales. Ecol. Soc. 2011, 16, 1. [CrossRef]

121. Jaeger, J.A.G.; Fahrig, L.; Ewald, K.C. Does the configuration of road networks influence the degree to which roads affect wildlife populations? In Proceedings of the 2005 International Conference on Ecology and Transportation, San Diego, CA, USA, 29 August 2005; Irwin, C.L., Garrett, P., McDermott, K.P., Eds.; Center for Transportation and the Environment, North Carolina State University: Raleigh, NC, USA, 2005.

122. Rhodes, J.R.; Lunney, D.; Callaghan, J.; McAlpine, C.A. A few large roads or many small ones? How to accommodate growth in vehicle numbers to minimise impacts on wildlife. PLoS ONE 2014, 9, 3. [CrossRef]

123. Bencin, H.L.; Prange, S.; Rose, C.; Popescu, V.D. Roadkill and space use data predict vehicle-strike hotspots and mortality rates in a recovering bobcat (Lynx rufus) population. Sci. Rep. 2019, 9, 1. [CrossRef]

124. Hebblewhite, M.; Haydon, D.T. Distinguishing technology from biology: A critical review of the use of GPS telemetry data in ecology. Philos. Trans. R. Soc. B Biol. Sci. 2010, 365, 2303-2312. [CrossRef]

125. Harris, S.; Morris, P.; Wray, S.; Yalden, D. A Review of British Mammals Population Estimates and Conservation Status of British Mammals Other Than Cetaceans; Joint Nature Conservation Committee: Peterborough, UK, 1995. 
126. Mathews, F.; Kubasiewicz, L.; Gurnell, J.; Harrower, C.; McDonald, R.; Shore, R.A. Review of the Population and Conservation Status of British Mammals; A report by the Mammal Society under contract to Natural England, Natural Resources Wales and Scottish Natural Heritage; Natural England: Peterborough, UK, 2018.

127. Schaus, J.; Uzal, A.; Gentle, L.K.; Baker, P.J.; Bearman-Brown, L.; Bullion, S.; Gazzard, A.; Lockwood, H.; North, A.; Reader, T.; et al. Application of the random encounter model in citizen science projects to monitor animal densities. Remotes Sens. Ecol. Conserv. 2020. [CrossRef]

128. Petrovan, S.O.; Vale, C.G.; Sillero, N. Using citizen science in road surveys for large-scale amphibian monitoring: Are biased data representative for species distribution? Biodivers. Conserv. 2020, 29, 1767-1781. [CrossRef]

129. Schwartz, A.L.W.; Williams, H.F.; Chadwick, E.; Thomas, R.J.; Perkins, S.E. Roadkill scavenging behaviour in an urban environment. J. Urb. Ecol. 2018, 4, 1-7. [CrossRef]

130. Péron, G.; Hines, J.E.; Nichols, J.D.; Kendall, W.L.; Peters, K.A.; Mizrahi, D.S. Estimation of bird and bat mortality at wind-power farms with superpopulation models. J. Appl. Ecol. 2013, 50, 902-911. [CrossRef]

131. Péron, G. Compensation and additivity of anthropogenic mortality: Life-history effects and review of methods. J. Anim. Ecol. 2013, 82, 408-417. [CrossRef]

132. Van der Grift, E.A.; van der Ree, R.; Fahrig, L.; Findlay, S.; Houlaham, J.; Jaeger, J.A.G.; Klar, N.; Madriñan, L.F.; Olson, L. Evaluating the effectiveness of road mitigation measures. Biodivers. Conserv. 2013, 22, 425-448. [CrossRef]

133. Glista, D.J.; DeVault, T.L.; DeWoody, J.A. A review of mitigation measures for reducing wildlife mortality on roadways. Landsc. Urban. Plan. 2009, 91,1-7. [CrossRef]

(C) 2020 by the authors. Licensee MDPI, Basel, Switzerland. This article is an open access article distributed under the terms and conditions of the Creative Commons Attribution (CC BY) license (http://creativecommons.org/licenses/by/4.0/). 